\title{
The Reality of the Application of Online Learning Media at the Sukareja 02 State Elementary School During the Covid-19 Pandemic
}

\author{
Komaludin \\ Sekolah Dasar Negeri Sukareja 02 \\ dwika.1189@gmail.com
}

\section{Article History}

received 3/12/2020

revised $17 / 12 / 2020$

accepted $31 / 12 / 2020$

\begin{abstract}
The Covid-19 pandemic has had a major impact on the world of education in Indonesia. Educators must ensure that teaching and learning activities continue, even though students are at home. This research was motivated by the state of teaching and learning activities at SDN Sukareja 02 during the covid-19 pandemic. The application of online learning media for teachers and students is a must during covid. -19. The purpose of this study was to determine the problems of online learning in SD Negeri Sukareja 02, Brebes Regency. This type of research is descriptive qualitative. The data collection technique was done by interview. Data analysis used in this research is data collection, data reduction, data presentation and conclusions. The results showed that the reality of online learning at SD Negeri Sukareja 02 was not ready to be implemented because there were still obstacles including learning applications, internet networks and devices, learning management, e-mail, and assessment.
\end{abstract}

Keywords: online learning, students, Covid-19

\begin{abstract}
Abstrak
Pandemi Covid-19 berdampak besar pada dunia Pendidikan di indonesia. Pendidik harus memastikan kegiatan belajar mengajar tetap berjalan, meskipun peserta didik berada di rumah.Penelitian ini dilatar belakangi oleh keadaan kegiatan belajar mengajar di SDN Sukareja 02 pada masa pandemi covid-19.Penerapan media pembelajaran daring bagi guru dan peserta didik merupakan suatu keharusan selama covid-19. Tujuan penelitian ini untuk mengetahui permasalahan pembelajaran daring di SD Negeri Sukareja 02 Kabupaten Brebes. Jenis penelitian ini merupakan kualitatif deskriptif. Teknik pengumpulan data dilakukan dengan wawancara. Analisis data yang digunakan dalam penelitian ini yaitu pengumpulan data, reduksi data penyajian data dan kesimpulan. Hasil penelitian menunjukkan bahwa realita pembelajaran daring di SD Negeri Sukareja 02 belum siap untuk diterapkan karena masih terdapat terkendala antara lain aplikasi pembelajaran, jaringan internet dan gawai, pengelolaan pembelajaran, dan penilaian.
\end{abstract}

Kata kunci: Pembelajaran daring,peserta didik, Covid-19

Social, Humanities, and Education Studies (SHEs): Conference Series https://jurnal.uns.ac.id/shes
p-ISSN 2620-9284

e-ISSN 2620-9292 


\section{PENDAHULUAN}

Sejak awal tahun 2020, organisasi kesehatan dunia atau yang dikenal sebagai WHO menetapkan bahwa Corona Virus Disease (Covid-19) sebagai pandemi, karena virus tersebut melanda lebih dari 200 negara di seluruh dunia. Di Indonesia mengantisipasi penyebaran Covid-19 dengan melakukan berbagai macam tindakan, mulai dari wajib memakai masker, work from home, study from home, social and physical distancing, pembatasan sosial berskala besar (PSBB). Anjuran untuk melakukan karantina selama pandemi juga dilakukan.Tindakan-tindakan tersebut diupayakan pemerintah agar seluruh masyarakat tidak terlibat dalam kerumunan yang dapat dengan mudah dalam penyebaran virus ini.

Seluruh jenjang pendidikan diharuskan untuk melakukan pembelajaran melalui sistem daring, tanpa terkecuali Sekolah Dasar (SD). Dengan adanya perubahan sistem pembelajaran daring sangat berdampak pada guru, siswa dan juga orang tua. Pembelajaran daring merupakan inovasi dalam dunia pendidikan dalam menyediakan sumber belajar yang bervariatif. Dalam kondisi seperti ini pembelajaran daring menjadi suatu langkah untuk mencapai proses belajar mengajar yang efektif dan efisien di bidang pendidikan (L. Dewi, 2017). Terdapat beberapa aplikasi yang dapat di manfaatkan dalam pembelajaran daring, yaitu zoom, google classroom, whatsapp group, dan lain sebagainya. Namun, pembelajaran daring tidak akan berjalan atau berhasil, tergantung dari lingkungan belajar dan karakteristik peserta didik. (W. A. F. Dewi, 2020) menjelaskan bahwa berhasilnya pembelajaran daring apabila guru, peserta didik, dan orang tua dapat bekerja sama.

Penelitian ini dilaksanakan dengan tujuan untuk mendeskripsikan realita pelaksanaan pembelajaran daring pada SDN Sukareja 02. Pelaksanaan pembelajaran selama masa pandemi covid-19 memberikan dampak positif dan negatif. Salah satu dampak positif dari pembelajaran secara daring atau jarak jauh adalah mengajak guru, siswa, dan orang tua mengenal teknologi, sedangkan dampak negatifnya belum siapnya SDM dan Perangkat ketika menerapkan pembelajaran jarak jauh (Widakdo \& Fananie, 2020).Selama pandemi Covid-19 semua proses pembelajaran dialihkan ke pembelajaran dalam jaringan (daring) apalagi untuk daerah dengan zona merah. Pembelajaran dilaksanakan dengan berbagai aplikasi yang dapat digunakan selama pembelajaran daring.

Pengaruh covid-19 memberikan dampak pada transformasi teknologi pada pendidikan di Indonesia khususnya jenjang sekolah dasar. Teknologi informasi adalah kata kunci dalam pembelajaran daring ataupun jarak jauh selama pandemi covid-19 agar memungkinkan peserta didik belajar lebih baik, lebih cepat, dan lebih pintar (Pujilestari, 2020). Istilah lain dikenal dengan ICT (Information and Communication Technology). UNESCO mengungkapkan bawa ada beberapa manfaat yang dapat diperoleh dengan menerapkan ICT dalam sistem pendidikan yaitu mempermudah dan memperluas akses jejaring pendidikan, meningkatnya kesetaraan pendidikan, mutu pembelajaran, profesionalisme guru serta lebih efektif dan efisien dalam manajemen dan tata kelola pendidikan.Guru dalam praktek pelaksanaan pembelajaran daring dan jarak jauh juga harus memiliki ICT literacy yang memadai agar memudahkan proses pembelajaran sehingga guru memerlukan pelatihan khusus untuk meningkatkan kompetensi ICTnya (König et al., 2020).

Penelitian ini bertujuan untuk mendeskripsikan problematika yang dialami guru dan peserta didik selama masa pandemi covid-19 yang menyebabkan transformasi digital pada dunia pendidikan khususnya pendidikan dasar di Indonesia. Beberapa penelitian yang relevan dengan penelitian ini adalah penelitian dengan judul dampak 
Covid-19 terhadap Implementasi Pembelajaran Daring di Sekolah Dasar dengan hasil penelitian bahwa proses pembelajaran secara daring dapat menggunakan berbagai aplikasi pendukung, sedangkan pembelajaran di kelas rendah memerlukan kerjasama antara orang tau dan guru karena anak belum mahir mengaopersikan perangkat dan aplikasi yang digunakan dalam proses pembelajaran (W. A. F. Dewi, 2020).Penelitian kedua dengan judul Dampak Covid-19 Terhadap Dinamika Pembelajaran di Indonesia, hasil penelitian yang diperoleh adalah dampak Covid pada pendidikan di Indonesia adalah 1) sekolah dialihkan ke rumah melalui proses pembelajaran daring; 2) terjadi transformasi media pembelajaran berbasis teknologi melalui penggunaan Wathshap Group, Zoom, Google Classroom, WebEx, Youtube, dan saluran TV (TVRI); 3) penyesuaian metode pembelajaran; 4) penyesuaian evaluasi pembelajaran untuk penentuan standar kenaikan kelas dan kelulusan; dan 5) tuntutan kolaborasi orangtua peserta didik di rumah sebagai pengganti guru mengontro pembelajaran anak (Mansyur, 2020). Penelitian ketiga dengan judul Kendala Pembelajaran Daring Guru Sekolah Dasar di Kabupaten Banjarnegara, hasil penelitiannya kendala yang dialami guru selama pembelajaran daring yaitu aplikasi pembelajaran, jaringan internet dan gawai, pengelolaan pembelajaran, penilaian, dan pengawasan (Rigianti, 2020).

\section{METODE}

Metode penelitian yang digunakan adalah metode penelitian diskriptif. Metode penelitian diskriptif tidak membuat perbandingan variabel itu pada sampel yang lain, dan mencari hubungan variabel itu dengan variabel yang lain.Tujuan penelitian diskriptif yaitu untuk menjelaskan, meringkaskan berbagai kondisi (H.M Burhan Bungin, 2011). Peneliti melakukan sebuah penelitian untuk melihat Bagaimanakah permasalahan yang dihadapi guru SD Negeri Sukareja 02. Penelitian melibatkan 1 guru kelas tinggi, 1 guru kelas rendah dan 4 peserta didik di setiap kelasnya. Persiapan Stabat dengan teknik pengumpulan data melalui wawancara.

\section{HASIL DAN PEMBAHASAN}

Proses belajar mengajar di sekolah dasar yang terjadi secara daring pada masa pademi Covid-19 menjadi hal yang baru dan menantang bagi kalangan guru. Jika dilihat secara sekilas, pembelajaran secara daring nampak begitu mudah. Ketika siswa dan guru memiliki gawai atau laptop serta jaringan internet, maka pembelajaran dapat dilaksanakan. Namun, faktanya ketika sudah memasuki pelaksanaan pembelajaran daring, kendala-kedala terkait pelaksanaan pembelajaran mulai dirasakan oleh para guru dan peserta didik di antanya yaitu:

1. Aplikasi Pembelajaran yang digunakan guru dan peserta didik untuk saling berkomunikasi adalah grup Whatsapp. Sebelum membentuk grup Wa, wali kelas mengumpulkan terlebih dahulu nomoh $\mathrm{Hp}$ untuk di share ke seluruh guru mata pelajaran.Hal ini bertujuan untuk memudahkan para guru membentuk grup wa masingmasing mata pelajaran.Kemudian para guru memanfaatkan aplikasi Ruang Guru untuk memudahkan dalam memberikan materi karena sudah tersedia video pembelajaran walau tidak semua mata pelajaran tersedia video pembelajarannya.Selain itu beberapa guru juga menggunakan aplikasi Zoom meeting.Kendala yang dihadapi adalah masih banyak guru dan siswa yang mengalami kesulitan dalam menggunakan aplikasi seperti zoom dan ruang guru dikarenakan belum terbiasa. 
2. Internet dan gawai Kebutuhan berikutnya dalam pembelajaran daring.Pembelajaran daring mustahil dilakukan tanpa internet dan gawai.Kendala yang dihadapi masih banyak gawai dari siswa yang memiliki kemampuan yang mumpuni,begitu juga dengan beberapa guru.Kemudian untuk jaringan internet sendiri beberapa daerah khususnya dilangkat jaringan internet belum stabil sehingga ketika diadakan pembelajaran sering terputus-putus terutama jika menggunakan aplikasi seperti zoom meeting.

3. Penilaian Kegiatan penilaian merupakan hal yang penting dan merupakan satu kesatuan dalam kegiatan belajar mengajar. Guna mendapatkan informasi mengenai pencapaian kompetensi siswa, maka dibutuhkan penilaian. Pelaksanaan pembelajaran daring menimbulkan masalah baru dalam hal penilaian siswa. Berdasarkan kurikulum 2013, penilaian kegiatan pembelajaran meliputi aspek afektif, kognitif dan psikomotor. Menurut Anderson (2003) terdapat tiga prinsip dalam penilaian pembelajaran, yaitu bermakna, transparansi dan adil. Ketiga prinsip tersebut tidak dapat dipenuhi secara maksimal oleh guru. Terutama prinsip adil. Adil dalam penilaian mempunyai makna bahwa setiap siswa mempunyai kesempatan yang sama dalam sistem penilaian., bukan berarti bahwa setiap siswa mendapatkan nilai yang sama, tetapi mendapatkan nilai yang sesuai dengan kemampuan belajar masing-masing. Fakta di lapangan, menunjukkan bahwa semua siswa memperoleh nilai maksimal ketika diberi soal. Hal tersebut menjadi pertanyaan bagi guru, apakah siswa benar-benar memahami materi atau siswa mendapatkan bantuan dari orang dewasa ketika mengerjakan tugas. Sehingga yang terjadi adalah guru tidak dapat menilai ketercapaian pembelajaran secara obyektif sesuai dengan kemampuan siswa. Dari sisi afektif, guru juga mengalami kesulitan dalam penilaian. Biasanya, penilaian afektif terjadi secara alamiah ketika siswa berinteraksi, berkomunikasi, dan bersosialisasi dengan teman. Adanya pembelajaran daring, menghilangkan sosialisasi siswa dengan siswa yang lain secara langsung. Sehingga menjadi kendala bagi guru dan siswa dalam melakukan penilaian afektif.

\section{SIMPULAN}

Perubahan pembelajaran dari tatap muka menjadi daring yang terjadi secara mendadak, memunculkan berbagai macam respon dan permasalahan bagi dunia pendidikan di Indonesia, tak terkecuali guru yang merupakan ujung tombak pendidikan yang langsung berhadapan dengan siswa. Sejumlah guru dan peserta didik mengalami kendala dalam melaksanakan pembelajaran daring diantaranya aplikasi pembelajaran, jaringan internet, gawai, dan , penilaian.

\section{DAFTAR PUSTAKA}

Dewi, W. A. F (2020). Dampak COVID-19 terhadap Implementasi Pembelajaran Daring di Sekolah Dasar. Edukatif: Jurnal IImu Pendidikan, 2(1), 55-61. https://doi.org/10.31004/edukatif.v2i1.89

Pujilestari, Y. (2020). Dampak Positif Pembelajaran Online Dalam Sistem Pendidikan Indonesia Pasca Pandemi Covid-19. Adalah, 4(1), 49-56. http://journal.uinjkt.ac.id/index.php/adalah/article/view/15394/7199

H.M Burhan Bungin. (2011). Metode Penelitian Kuntitatif: Komunikasi, Ekonomi, dan Kebijakan Publik serta IImu-ilmu lainnya, Edisi Kedua (2nd ed.). Jakarta: 
Kencana Prenama Media Group. Kementrian Pendidikan dan Kebudayaan Republik Indonesia. 2020. Surat Edaran Surat Edaran No. 4 Tahun 2020 tentang Pelaksanaan Kebijakan Pendidikan dalam Masa Darurat Penyebaran Corona Virus Disease (Covid19).

König, J., Jäger-Biela, D. J., \& Glutsch, N. (2020). Adapting to online teaching during COVID-19 school closure: teacher education and teacher competence effects among early career teachers in Germany. European Journal of Teacher Education, 43(4), 608-622. https://doi.org/10.1080/02619768.2020.1809650.

Mansyur, A. R. (2020). Dampak COVID-19 Terhadap Dinamika Pembelajaran Di Indonesia. Education and Learning Journal, 1(2), 113.https://doi.org/10.33096/eljour.v1i2.55

Rohmah, L., (2016). Konsep E-Learning Dan Aplikasinya Pada Lembaga Pendidikan Islam. An-Nur: Jurnal Studi Islam. 3(2),

Ruseffendi, E.T, 2006, Pengantar Kepada Guru Mengembangkan Kompetensinya dalam Pengajaran Matematika Untuk Meningkatkan CBSAI. Bandung:

Rigianti,HA.(2020) Kendala Pembelajaran Daring Guru Sekolah Dasar Di Kabupaten Banjarnegara. Elementary School. Volume 7,297-302

Tarsito. Setyosari, punaji. (2012). Metode Penelitian Pengembangan. Jakarta: Kencana. Sugiyono. 2016. Metode Penelitian Kombinasi (8th ed.). Bandung: Alfabeta.

Ulfa, M. (2019). Strategi Preview, Question, Read, Reflect, Recite, Review (PQ4R) pada Pemahaman Konsep Matematika. Mathema Journal Pendidikan Matematika. 1(1), 48-55. Yazdi, M. 2012. E-Learning Sebagai Media Pembelajaran Interaktif Berbasis Teknologi Informasi. Jurnal Ilmiah Foristek. 2(1).

Widakdo, J., \& Fananie, K. G. B. (2020). Dampak Positif Pembelajaran Online Dalam Sistem Pendidikan Indonesia Pasca Pandemi Covid-19. In Perhimpunan Pelajar Indonesia Se-(Vol.4,Issue 1).

http://journal.uinjkt.ac.id/index.php/adalah/article/view/15394/7199 